\title{
PENGARUH PERNIKAHAN DINI TERHADAP TERJADINYA
} PARTUS LAMA

\section{EFFECT OF EARLY MARRIAGE OF OCCURRENCE PARTUS}

\author{
Nur Hidayati, Juni Setiawan \\ Akademi Kebidanan Ibrahimy Sukorejo Situbondo \\ Email : nurhidayati@akbidibrahimy.ac.id
}

\begin{abstract}
ABSTRAK
Pernikahan dini adalah pernikahan yang dilakukan oleh pasangan suami isteri dimana keduanya masih di bawah umur 21 tahun yaitu 19 tahun untuk laki - laki dan 16 tahun bagi perempuan. Partus lama adalah persalinan yang abnormal yang ditandai oleh kelambatan atau tidak adanya kemajuan proses persalinan dalam ukuran satuan waktu tertentu. Tujuan penelitian ini adalah untuk mengetahui adanya pengaruh pernikahan dini terhadap terjadinya partus lama di Desa Sumberwaru Kecamatan Banyuputih Kabupaten Situbondo. Desain penelitian ini menggunakan penelitian analitik, dengan rancangan Cross Sectional, dengan sample $68 \mathrm{ibu}$ yang menikah dini di Desa Sumberwaru dan menggunakan tekhnik simple random sampling,.Uji statistik yang digunakan adalah Wilcoxon Signed Rank Test dengan bantuan Komputer program SPSS 16. Hasil penelitian menunjukkan bahwa ada pengaruh yang signifikan $(\mathrm{p}=0,000)$ yaitu $(0,000<0,05)$ antara pernikahan dini dengan terjadinya partus lama. Dapat disimpulkan bahwa ada pengaruh pernikahan dini terhadap terjadinya partus lama. Untuk itu diharapkan bagi para remaja tidak menikah pada usia kurang dari 21 tahun dan menunda kehamilan pertamanya hingga mencapai usia 20 tahun agar tidak timbul kemungkinan terjadinya persalinan yang lama, perdarahan, dan konflik yang berujung perceraian.
\end{abstract}

Kata Kunci : Pernikahan Dini, Partus Lama.

\begin{abstract}
Early marriage is a marriage performed by married couples where both are still under 21 years of age is 19 years for men - men and 16 years for women. While prolonged labor is labor that is abnormal characterized by slowness or lack of progress of labor in a certain time unit size. The purpose of this study was to investigate the effect of early marriage on the occurrence of prolonged labor in the village Sumberwaru Banyuputih District of Situbondo. This study design using analytical research, with cross sectional design, with a sample of 68 mothers of 84 women who married early in Sumberwaru village. And using simple random sampling technique. Uji statistic used is the Wilcoxon Signed Rink Test with the help of computer program SPSS 16. The results showed that there was significant effect $(\mathrm{p}=0.000)$, namely $(0.000<0.005)$ between early marriage with the occurrence of prolonged labor. It can be concluded that there was influence of early marriage on the occurrence of prolonged labor. For that is expected for the adolescent not married at usi less than 21 years and delaying the first pregnancy until reaching the age of 20 years in order to avoid the possibility of a long labor, bleeding, and the conflicts that led to divorce.
\end{abstract}

Keywords: Early Marriage, Prolonged Labor.

\section{PENDAHULUAN}

Manusia

dalam

proses

perkembangannya untuk meneruskan

jenisnya membutuhkan pasangan hidup

yang dapat memberikan keturunan

sesuai dengan apa yang diinginkannya.
Tujuan pernikahan yaitu untuk membentuk suatu keluarga atau rumah tangga bahagia dan kekal berdasarkan Ketuhanan Yang Maha Esa. Hal ini dimaksudkan bahwa pernikahan itu hendaknya berlangsung seumur hidup 
dan tidak boleh berakhir begitu saja. Oleh karena itu dalam sebuah pernikahan sangat penting memperhatikan batasan usia karena di dalam pernikahan juga menghendaki kematangan psikologi dan kesiapan alat reproduksi. Penentuan batas minimal usia dalam pernikahan sangat penting karena secara tidak langsung memengaruhi kualitas dalam kehidupan berumah tangga. Keluarga yang berkualitas akan melahirkan sebuah generasi yang lebih baik. Oleh karena itu dalam peraturan perundangan dijelaskan bahwa ada batas usia untuk melangsungkan pernikahan.

Ketentuan batas usia tersebut terdapat dalam pasal 7 ayat 1 UU No. 1 Tahun 1974, pernikahan dini adalah pernikahan yang dilakukan oleh pasangan suami isteri dimana keduanya masih di bawah umur 21 tahun yaitu 19 tahun untuk laki - laki dan 16 tahun bagi perempuan. Dari batas usia tersebut dapat ditafsirkan bahwa UU No 1 tahun 1974 tidak menghendaki pernikahan yang dilakukan oleh mereka yang berusia di bawah ketentuan tersebut atau melangsungkan pernikahan di bawah umur. Undang-undang pernikahan tersebut bertolak belakang dengan UU No 23 tahun 2012 tentang Perlindungan
Anak Indonesia (PAI) dijelaskan bahwa anak sampai usia 18 tahun masih menjadi tanggung jawab dan di bawah perlindungan orang tua, sehingga mereka baru diperbolehkan melaksanakan pernikahan di atas 18 tahun. Selebihnya pernikahan dilakukan di bawah batas minimal ini disebut pernikahan dini.

Badan Kependudukan Keluarga Berencana Nasional (BKKBN) yang menyatakan bahwa usia pernikahan pertama diijinkan apabila pihak pria mencapai umur 25 tahun dan wanita mencapai umur 20 tahun, dengan alas an karena masih dalam masa reproduksi, usia di bawah 20 tahun adalah usia yang dianjurkan untuk menunda pernikahan dan kehamilan, karena dalam usia ini banyak risiko yang mungkin terjadi, sebab kondisi rahim dan panggul belum berkembang optimal.

Umur ibu saat melahirkan mempunyai pengaruh terhadap terjadinya partus lama, ibu dengan umur di bawah 20 tahun, rahim dan panggul sering kali belum tumbuh mencapai ukuran dewasa. Akibatnya ibu hamil pada umur tersebut mungkin mengalami persalinan lama atau macet atau gangguan lainnya.

Partus lama menimbulkan efek berbahaya baik terhadap ibu maupun 
anak. Beratnya cedera meningkat dengan semakin lamanya proses persalinan, resiko tersebut naik dengan cepat setelah waktu 24 jam. Terdapat kenaikan pada insidensi atonia uteri, laserasi, perdarahan, infeksi, kelelahan ibu dan shock. Sedangkan efek berbahaya pada janin salah satunya adalah terjadinya asfiksia, trauma pada janin seperti terdapat caput succedenum dan pecahnya ketuban sebelum kelahiran sehingga mengakibatkan terinfeksinya cairan ketuban selanjutnya dapat membawa infeksi paru-paru serta infeksi sistemik pada janin (Mochtar, dalam Nugroho, 212:245).

Sesuai dengan hasil penelitian di Makassar yang dilakukan oleh Indrayani tahun 2006 dengan menggunakan desain penelitian case control study menemukan ibu yang mengalami partus lama kemungkinan 1,8 lebih besar berumur $<20$ tahun dibandingkan umur 20-35 tahun.

Dalam hasil Riset Kesehatan Dasar (RISKESDAS) 2013 menyebutkan bahwa diantara perempuan 10-54 tahun,26 persen menikah pertama kali pada umur kurang dari 15 tahun dan 23,9 persen menikah pada umur 15-19 tahun.

Sementara itu data pernikahan dini di Kabupaten Situbondo pada tahun 2014 terdapat 88 remaja yang menikah di bawah usia 20 tahun. Sedangkan data dari Kantor Urusan Agama (KUA) Kecamatan Banyuputih tahun 2014 menyebutkan bahwa pernikahan dini di Desa Sumberwaru terdapat 84 orang (80\%) dari 105 orang yang menikah, dan hanya 21 orang $(20 \%)$ yang tidak menikah di usia dini.

Berdasarkan latar belakang dan studi pendahuluan di atas maka perlu dilakukan penelitian lebih lanjut tentang "Pengaruh Pernikahan Dini Terhadap terjadinya partus lama di Desa Sumberwaru Kecamatan Banyuputih Kabupaten Situbondo"

\section{METODE PENELITIAN}

Desain penelitian yang digunakan adalah penelitian Analitik (Non Eksperimen), dengan rancangan cross sectional. Populasi pada penelitian ini adalah semua ibu yang menikah dini yang ada di Desa Sumberejo Kecamatan Banyuputih Kabupaten Situbondo sebanyak 84 orang. Besar sampel dalam penelitian ini berjumlah 68 orang.

Tekhnik pengambilan sampel yang di gunakan adalah menggunakan tabel Ishach dan Robert dengan taraf kesalahan 5\% (Notoatmodjo, 2012: 130). 
HASIL DAN PEMBAHASAN

Tabel 1. Distribusi Frekuensi Responden tentang Pernikahan Dini berdasarkan Pendidikan ibu di Desa Sumberwaru Kecamatan Banyuputih Kabupaten Situbondo.

\begin{tabular}{|c|c|c|c|}
\hline No & Pendidikan & Frekuensi & $\begin{array}{c}\text { Persentase } \\
(\%)\end{array}$ \\
\hline 1 & SD & 2 & 3 \\
\hline 2 & SMP & 19 & 27,90 \\
\hline 3 & SMA & 35 & 51,48 \\
\hline 4 & PT & 12 & 17,62 \\
\hline No & Pekerjaan ortu & Frekuensi & $\begin{array}{c}\text { persentase } \\
(\%)\end{array}$ \\
\hline 1 & Buruh & 13 & 19,12 \\
\hline 2 & Nelayan & 6 & 8,8 \\
\hline 3 & Wiraswasta & 38 & 55,90 \\
\hline \multirow[t]{3}{*}{4} & PNS & 11 & 16,8 \\
\hline & Total & 64 & $100 \%$ \\
\hline & Total & 64 & 100 \\
\hline
\end{tabular}

responden mempunyai pendidikan SMA

adalah 35 orang $(51,48 \%)$ dan sebagian

kecil responden mempunyai pendidikan

SD adalah 2 orang (3\%).

Tabel 2. Distribusi Frekuensi Responden tentang Pernikahan Dini berdasarkan Pekerjaan Orang tua di Desa Sumberwaru Kecamatan Banyuputih Kabupaten Situbondo.

Berdasarkan tabel 2 sebagian besar orang tua responden bekerja sebagai wiraswasta adalah 38 orang $(55,90 \%)$ dan sebagian kecil orang tua responden bekerja sebagai nelayan adalah 6 orang $(8,8 \%)$.

Tabel 3. Distribusi Frekuensi Responden tentang Pernikahan Dini Berdasarkan Umur Ibu Di Desa Sumberwaru Kecamatan Banyuputih Kabupaten Situbondo

\begin{tabular}{cccc}
\hline No & umur (tahun) & frekuensi & persentase (\%) \\
\hline 1 & & & 5,8 \\
2 & 46 & 4 & 36,80 \\
3 & $16-18$ & 25 & 57,40 \\
\hline & $19-20$ & 39 & 100 \\
\hline
\end{tabular}

Berdasarkan tabel 3 Sebagian Besar usia responden antara 19-20 tahun adalah 39 orang $(57,40 \%)$ dan sebagian kecil usia responden $\leq 6$ tahun adalah 4 orang $(5,8 \%)$.

Tabel 4. Distribusi Frekuensi Pengaruh Pernikahan Dini terhadap terjadinya Partus lama di Desa Sumberwaru Kecamatan Banyuputih Kabupaten Situbondo

\begin{tabular}{cccc}
\hline No & Partus lama & frekuensi & Persentase $(\%)$ \\
\hline 1 & Lama & 38 & 55,90 \\
2 & Cukup lama & 25 & 36,80 \\
3 & Sangat lama & 5 & 7,3 \\
\hline & Total & 64 & 100
\end{tabular}

Berdasarkan tabel 4 sebagian besar responden mengalami riwayat Persalinan Lama adalah 38 orang $(55,90 \%)$ dan sebagian kecil responden mengalami riwayat Persalinan Cukup Lama adalah 5 orang (7,3\%).

Tabel 5. Pengaruh Pernikahan Dini terhadap terjadinya Partus Lama di Desa Sumberwaru Kecamatan Banyuputih Kabupaten Situbondo

\begin{tabular}{|c|c|c|c|c|c|c|c|c|}
\hline \multirow{3}{*}{ Pernikahan dini } & \multicolumn{6}{|c|}{ Partus lama } & \multirow{2}{*}{\multicolumn{2}{|c|}{ Total }} \\
\hline & \multicolumn{2}{|c|}{ Lama } & \multicolumn{2}{|c|}{ Cukup lama } & \multicolumn{2}{|c|}{ Sangat lama } & & \\
\hline & $\mathrm{F}$ & $\%$ & $\mathrm{~F}$ & $\%$ & $\mathrm{~F}$ & $\%$ & $\mathrm{~F}$ & $\%$ \\
\hline$<16$ & 3 & 4,4 & 1 & 1,4 & 0 & 0 & 4 & 5,8 \\
\hline $16-18$ & 11 & 17,18 & 10 & 15,32 & 3 & 4,3 & 25 & 36,80 \\
\hline $19-20$ & 24 & 35,30 & 14 & 19,20 & 2 & 2,9 & 39 & 57,40 \\
\hline Total & 38 & 55,90 & 25 & 36,80 & 5 & 7,3 & 68 & 100 \\
\hline
\end{tabular}


Berdasarkan tabel 5 hampir seluruhnya responden dengan pernikahan dini berusia 19-20 tahun dengan kejadian partus lama sebanyak 24 orang $(35,30 \%)$, kemudian pada kejadian persalinan cukup lama sebanyak 14 orang $(19,20 \%)$ dan pada kejadian sangat lama sebanyak 2 orang $(2,9 \%)$. Sedangkan sebagian kecil responden berusia $<16$ tahun dengan kejadian partus lama adalah 3 orang $(4,4 \%)$, kemudian pada kejadian persalinan cukup lama adalah 1 orang $(1,4 \%)$ pada kejadian sangat lama adalah 0 orang $(0 \%)$.

Badan Kependudukan Keluarga Berencana Nasional (BKKBN) tahun 2009 yang menyatakan bahwa usia pernikahan pertama diijinkan apabila pihak pria mencapai umur 25 tahun dan wanita mencapai umur 20 tahun, dengan alasan karena masih dalam masa reproduksi, usia dibawah 20 tahun adalah usia yang dianjurkan untuk menunda pernikahan dan kehamilan, karena dalam usia ini banyak risiko yang mungkin terjadi, sebab kondisi rahim dan panggul belum berkembang optimal.

Umur ibu saat melahirkan mempunyai pengaruh terhadap terjadinya partus lama, ibu dengan umur di bawah 20 tahun, rahim dan panggul sering kali belum tumbuh mencapai ukuran dewasa. Akibatnya ibu hamil pada umur tersebut mungkin mengalami persalinan lama atau macet atau gangguan lainnya (Marmi, 2013: 55).

Usia terbaik bagi wanita untuk hamil dan melahirkan adalah pada umur 20-30 tahun. Pada usia ini keadaan kesehatan fisik dan mental wanita dalam keadaan optimal. Jika pernikahan dan kehamilan dilakukan pada usia terlalu muda (kurang dari 20 tahun) maka ini akan berisiko melemahkan kesehatan wanita, karena pada masa ini yang sering juga disebut masa remaja, masa remaja adalah masa transisi (peralihan) antara masa anak-anak dan masa dewasa. Di usia ini belum sepenuhnya matang baik secara fisik, kognitif, dan psikososial. Dalam masa ini cepat sekali terpengaruh oleh lingkungan. Kehamilan yang terjadi pada usia ini tidak hanya bermasalah pada kematangan fisik dan psikis yang belum sempurna tetapi juga karena pendidikan yang rendah, sosialisasi yang kurang, konflik dengan keluarga, kecemasan dan lenyapnya sumber keuangan terutama mereka yang lari dari rumah.

Pernikahan dini yang terjadi di Desa Sumberwaru ini rata-rata berkisar antara usia 19-20 tahun, dimana pada masa ini 
adalah puncak dari masa keremajaan. Dan dari 68 orang yang menikah dini dan sudah melahirkan dilihat dari riwayat persalinannya yaitu mengalami persalinan yang lama. Hal ini dibuktikan dengan teori yaitu persalinan pada kehamilan remaja akan mengalami persalinan yang lama yang disebabkan oleh kelainan letak janin, kelainan panggul, kelainan kekuatan His, dan mengejan serta pimpinan persalinan yang salah (Manuaba, 2008: 223).

Dari penelitian yang telah dilakukan dapat disimpulkan bahwa kondisi ibu pada masa persalinan pada penelitian ini ditemukan memiliki rata-rata lama proses persalinan 12-15 jam (>12 jam) hal ini termasuk dalam kategori Lama. Dan semua ibu pada penelitian ini yaitu Primigravida atau baru pertama kali hamil dan melahirkan. Waktu yang diperlukan seorang primigravida dan primipara melahirkan normalnya 12 jam, sehingga hasil penelitian ini menunjukkan adanya proses persalinan yang lama, melihat fenomena tersebut sebaiknya bagi para remaja tidak menikah pada usia kurang dari 20 tahun dan menunda kehamilan pertamanya hingga mencapai usia 20 tahun agar tidak timbul kemungkinan terjadinya persalinan yang lama.
Oleh karena itu menilai bahwa pernikahan di usia muda (pernikahan dini) di Desa Sumberwaru masih sangat tinggi karena penulis masih banyak menemukan pernikahan dini dilakukan atas kemauan sesaat tanpa memikirkan sebab akibat yang ditimbulkan dan pada akhirnya akan berujung pada perceraian.

\section{SIMPULAN DAN SARAN}

Simpulan penelitian ini yaitu hampir seluruhnya wanita yang menikah dini yaitu berusia 19-20 tahun sebanyak 57 orang $(83,80 \%)$ di Desa Sumberwaru Kecamatan Banyuputih Kabupaten Situbondo. Sebagian besar wanita yang menikah dini mengalami riwayat persalinan lama yaitu 12-15 jam adalah 38 orang $(55,90 \%)$ di Desa Sumberwaru Kecamatan Banyuputih Kabupaten Situbondo. Dan terdapat pengaruh pernikahan dini terhadap terjadinya partus lama di Desa Sumberwaru Kecamatan Banyuputih Kabupaten Situbondo.

\section{DAFTAR PUSTAKA}

BKKBN. 2009. Buku Panduan PLKB/PKB Dampak Pernikahan Usia Dini bagi Keluarga. Surabaya: BKKBN. 
Budianto. 2009. Biostatistik untuk kedokteran dan kesehatan. Jakarta:EGC.

Cahyaningsih D. 2011. Pertumbuhan perkembangan anak dan remaja. Jakarta: Truns Info Media.

Dahro A. Psikologi kebidanan analisis perilaku wanita untuk kesehatan. Jakarta: Salemba Medika.

Filderia. Hubungan antar usia, paritas dengan persalinan kala II lama. 2013. Embrio Jurnal Kebidanan.
Hidayat. 2013. Metode penelitian kuantitatif. Surabaya: Health Books.

Kusmiran. 2012.Kesehatan reproduksi remaja dan wanita. Jakarta: Salemba medika.

Mansur. 2012. Psikologi ibu dan anak untuk kebidanan. Jakarta: Salemba Medika.

Manuaba I. 2009. Ilmu kebidanan, penyakit kandungan \& keluarga berencana untuk Pendidikan bidan. Jakarta:EGC.

Marni. 2013. Kesehatan Reproduksi. Yogyakarta: Pustaka Belajar. 